DOI: $10.4274 /$ tod. 47113

Turk J Osteoporos 2017;23:47-51

\title{
The Effectiveness of Transcutaneous Electrical Nerve Stimulation in Knee Osteoarthritis with Neuropathic Pain Component: A Randomized Controlled Study
}

\author{
Nöropatik Ağrı Komponenti Olan Diz Osteoartritinde Transkutanöz Elektrik Sinir \\ Stimülasyonu Etkinliği: Randomize Kontrollü Çalışma
}

Cemile Sevgi Polat, Asuman Doğan, Didem Sezgin Özcan, Belma Füsun Köseoğlu, Sinem Koçer Akselim, Şule Şahin Onat Ankara Physical Therapy and Rehabilitation Training and Research Hospital, Clinic of Physical Therapy and Rehabilitation, Ankara, Turkey

\section{Abstract}

Objective: The aim of our study was to assess the efficacy of transcutaneous electrical nerve stimulation (TENS) in knee osteoarthritis with neuropathic pain component.

Materials and Methods: The patients were assessed by visual analogue scale (VAS) for pain severity, Western Ontario and McMaster osteoarthritis index (WOMAC) for physical function and the Kellgren-Lawrence system for severity of osteoarthritis, painDETECT questionnaire for presence of neuropathic pain. Patients were divided into two groups according to painDETECT questionnaire scores. Group 1 consisted of 20 patients (39.2\%) with likely and possible neuropathic pain, group 2 consisted of 31 patients (60.8\%) with unlikely neuropathic pain. All patients received hot pack, TENS and home exercise program was given. Physical therapy agents were given for 3 weeks, 5 days a week. Assessments were evaluated in all patients before and after the treatment.

Results: There was no statistically significant difference in demographic features and radiographic evaluations between the groups. The VAS, WOMAC pain and physical function scores were significantly lower after treatment in knee patients with neuropathic pain component, but there was no significant difference between the two groups.

Conclusion: TENS is a neuropathic pain component in knee osteoarthritis patients, which is effective in reducing pain and improving physical function. The benefit of TENS therapy is that it can be used in conjunction with drug therapy, thereby reducing the drug dose and drug side effects.

Keywords: Neuropathic pain, knee osteoarthritis, transcutaneous electrical nerve stimulation

\section{Öz}

Amaç: Çalışmamııın amacı nöropatik ağrı komponenti olan diz osteoartritinde transkütanöz elektriksel sinir stimülasyonunun (TENS) etkinliğini araştırmaktır.

Gereç ve Yöntem: Hastalar ağı şiddeti açısından görsel analog skala (VAS), fiziksel fonksiyon için Western Ontario ve McMaster osteoartriti indeks (WOMAC), osteoartrit şiddeti açısından Kellgren-Lawrence derecelendirme, nöropatik ağrı varlığı açısından painDETECT ağrı anketi ile değerlendirildi. Hastalar painDETECT puanlarına göre 2 gruba ayrıldı. Grup 1 nöropatik ağrısı pozitif ve muhtemel olan 20 (\%39,2) hastadan, grup 2 nöropatik ağrısı olmayan $31(\% 60,8)$ hastadan oluşmaktadır. Bütün hastalar hot pack ve TENS tedavisi aldı, ev egzersiz programı verildi. Fiziksel tedavi ajanları haftada 5 gün olmak üzere 3 hafta verildi. Değerlendirmeler bütün hastalarda tedavi öncesi ve sonrası yapıldı. Bulgular: Demografik özellikler ve radyografik değerlendirme açısından gruplar arasında istatiksel olarak fark yoktu. VAS, WOMAC ağrı ve fiziksel fonksiyon skorları nöropatik ağrı komponenti olan diz hastalarında tedaviden sonra anlamlı derecede azaldı fakat her iki grup arasında anlamlı farklılık yoktu.

Sonuç: TENS nöropatik ağı komponenti olan diz osteoartriti hastalarında ağrıyı azaltmada ve fiziksel fonksiyonu geliştirmede etkilidir. TENS tedavisinin avantajı ilaç tedavisi ile birlikte kullanılabilmesi böylelikle ilaç dozunun ve ilaç yan etkilerinin azaltılmasını sağlamasıdır.

Anahtar kelimeler: Nöropatik ağrı, diz osteoartriti, transkütanöz elektriksel sinir stimülasyonu

Address for Correspondence/ Yazıșma Adresi: Cemile Sevgi Polat MD, Ankara Physical Therapy and Rehabilitation Training and Research Hospital, Physical Therapy and Rehabilitation, Ankara, Turkey Phone: +90 5056354605 E-mail: drsevgipolat@hotmail.com ORCID ID: orcid.org/0000-0002-1037-1476 Received/Geliş Tarihi: 01.12.2016 Accepted/Kabul Tarihi: 16.11.2017 


\section{Introduction}

Historically, the pain of osteoarthriti (OA) knee has been considered to be nociceptive pain but cumulative data suggest that both nociceptive and neuropathic mechanisms can play role in the pain of OA $(1,2)$. Transcutaneous electrical nerve stimulation (TENS) is commonly used physical therapy modality for the treatment of pain caused by OA $(3,4)$. TENS strengthens local inhibitory control and is indicated in focal neuropathic pain (NP) (5). The analgesic effect of TENS is similar to that achieved with opioid agonists in the treatment of NP (6).

There are only a limited number of studies that use TENS for treatment of different NP conditions (7-9). These studies suggest that TENS is a reasonable treatment to manage NP (10). Due to the presence of NP component in some knee OA patients we considered to investigate the effects of TENS in this patient population. To our knowledge the effect of TENS has not been investigated for the treatment of NP in knee OAs. The purpose of this study was to investigate whether TENS could reduce the severity of NP in knee OAs and to compare the effects of TENS in knee OA with and without NP component.

\section{Materials and Methods}

Fifty one women patients who treated in Ankara Physical Medicine and Rehabilitation Training and Research Hospital were randomly enrolled in this study. The Local Ethics Committee of Ankara Physical Medicine and Rehabilitation Training and Research Hospital approved the study and written consent was taken from each patient. Knee OA was diagnosed according to the American College of Rheumatology criteria. Each patient's knee $\mathrm{X}$-rays were taken while the patient was standing, knee extended in anteroposterior position. Each knee was staged according to the Kellgren and Lawrence (11) radiological stage. All patients (>45 years) had knee pain for more than 3 months. Patients with any previous history of knee surgery (arthroscopy and total knee replacement), infection, rheumatoid arthritis and other pain/neurological conditions such as radiculopathies, coxarthrosis, stroke, traumatic brain injury and were already receiving medical treatment for NP were excluded from the study.

Demographic characteristics (age, work status, educational level, body mass index, comorbidities) and pain duration of the patients were recorded. All patients completed the painDETECT questionnaire (PDQ) for presence of NP. The patients were divided into two groups according to the PDQ scores. Group 1 consisted of patients with likely and possible NP and group 2 consisted of patients with unlikely NP. Assessment of pain [visual analog scale (VAS); Western Ontario McMaster Osteoarthritis Index (WOMAC pain score)], disability and stiffness (WOMAC physical function and stiffness score) were done in all patients before and after the treatment. All patients received TENS (20 $\mathrm{min} /$ day) and hot pack (20 min/day). They were applied 5 days a week for 3 weeks in total. Everyway (EV-603M) branded device was used for the TENS treatment. The TENS was applied at a frequency of 80 hertz with 10 to $30 \mathrm{~mA}$ intensity. Four electrodes were placed on the anterior medial and lateral portions of the knee. All the patients completed 15 treatment sessions. Physiotherapists who applied physical therapy agents were blinded, they didn't know about the study and patients' different groups. All patients were given a home exercise program at the beginning of the treatment. Patients were directed to perform the exercise program, including quadriceps isometric and strengthening exercises, for 10 repetitions of the set, 2 times a day for three weeks.

\section{Scales}

The painDETECT questionnaire: It is used to evaluate the features of pain experienced by participants in the preceding four weeks. It contains a body drawing for patients to show the sites of pain and any radiation present, evaluation of pain quality with a marker of severity from hardly noticed to very strongly, pattern of pain and measures of current, worst and average pain severity. The PDQ score ranges from 0 to 38; a score $\geq 19$ indicates likely NP, $\geq 13$ to $\leq 18$ indicates possible NP, and $\leq 12$ indicates unlikely NP (12). The Turkish version of the PDQ was developed and validity and reliability studies were conducted (13).

Visual analog scale: The VAS consists of a $10 \mathrm{~cm}$ line, with the left extreme indicating "no pain or zero" and the right extreme indicating "unbearable pain or 10" (14).

Western Ontario McMaster osteoarthritis index: This scale consists of subsections for pain (5 questions), stiffness (2 questions) and physical functionality (17 questions). In 5-point Likert form, 0 is none while 4 is extreme pain, with 0 as the best and 96 as the worst. The Turkish reliability and validity studies were conducted by Tüzün et al. (15).

\section{Statistical Analysis}

Data was analyzed by using SPSS 20.0 (SPSS Inc., Chicago, IL, USA). Distribution of continuous variables was evaluated by Shapiro-Wilk test. Descriptive statistics were expressed as mean \pm standard deviation (SD) for continuous variables and as median (minimum-maximum) for discrete variables. Number and percentage (\%) were expressed for categorical variables. Comparisons between the groups in terms of sociodemographic and clinical characteristics were measured by Kruskal-Wallis test for mean values, Mann-Whithey $U$ test for median values and chi-square test (or Fisher's exact test) for categorical variables. The Wilcoxon Signed-Ranks test was used to determine statically significant changes in VAS and WOMAC scores between before and after the treatment. $\mathrm{P}<0.05$ was considered statistically significant.

\section{Results}

The comparison of socio-demographic characteristics, clinical properties and radiographic evaluation of the groups was shown in Table 1. There was no statistically significant difference in these parameters between the groups except baseline pain 


\begin{tabular}{|c|c|c|c|}
\hline & $\begin{array}{l}\text { Group } 1 \\
(n=20)\end{array}$ & $\begin{array}{l}\text { Group } 2 \\
(n=31)\end{array}$ & $\mathbf{p}$ \\
\hline Age (years) & $65.4 \pm 8.41$ & $62.77 \pm 9.10$ & 0.30 \\
\hline BMI $\left(\mathrm{kg} / \mathrm{m}^{2}\right)$ & $32.46 \pm 5.08$ & $33.21 \pm 5.03$ & 0.60 \\
\hline \multicolumn{4}{|c|}{ Educational level n (\%) } \\
\hline Illiterate & $3(15)$ & $6(19.35)$ & 0.92 \\
\hline $\begin{array}{l}\text { Primary school } \\
\text { High school }\end{array}$ & $\begin{array}{l}13(65) \\
4(20)\end{array}$ & $\begin{array}{c}9(61.3) \\
6(19.35)\end{array}$ & \\
\hline \multicolumn{3}{|l|}{ Work status n (\%) } & \multirow{3}{*}{0.66} \\
\hline Working & $1(5)$ & $2(6.5)$ & \\
\hline Housewife/retired & $19(95)$ & $29(93.5)$ & \\
\hline \multicolumn{4}{|c|}{ VAS median(min-max) } \\
\hline Rest & $5(2-8)$ & $3(0-8)$ & 0.01 \\
\hline Activity & $8(7-10)$ & $7(5-8)$ & 0.01 \\
\hline \multicolumn{4}{|c|}{ Kellgren-Lawrence scale } \\
\hline Grade 1 & $0(0)$ & $1(3.2)$ & 0.14 \\
\hline Grade 2 & $3(15)$ & $12(38.7)$ & \\
\hline Grade 3 & $11(55)$ & $14(45.2)$ & \\
\hline Grade 4 & $6(30)$ & $4(12.9)$ & \\
\hline \multicolumn{4}{|l|}{ WOMAC scores } \\
\hline Pain & $13.5(7-20)$ & $10(5-18)$ & 0.01 \\
\hline Stiffness & $2.5(0-6)$ & $2(0-6)$ & 0.38 \\
\hline Physical function & $43(20-40)$ & $34(18-52)$ & 0.11 \\
\hline \multicolumn{4}{|c|}{$\begin{array}{l}\text { n: Number of patients per group, \%: Percantage of patients per group, } \\
(p<0.05) \text { is considered as statistically significant, BMI: Body mass index, VAS: } \\
\text { Visuel analog scale, WOMAC: Western Ontario McMaster Osteoarthritis Index }\end{array}$} \\
\hline
\end{tabular}

at rest and activity $(p<0.05)$. The comparison of treatment changes $(\Delta)$ of the clinical parameters according to baseline values (mean \pm SD) was demonstrated in Table 2. According to, within each group, significant improvements were observed in all clinical variables $(p<0.05)$. The comparison of treatment changes of the clinical parameters according to baseline values was shown in Table 3. According to baseline values, there was no significant differences in the changes in outcome scores $(\Delta)$ between the groups ( $p>0.05)$.

\section{Discussion}

TENS is a recommended treatment for relief of pain in recent guidelines for the management of knee OA. The use of TENS is important due to considerable gastrointestinal and cardiac side effects of pharmacological agents commonly used in the treatment of OA (16). There have been a number of systematic review/meta-analyses that have explored efficacy of TENS in knee OA. As a whole, these reviews are conflicting with some showing efficacy and some showing no efficacy for the use

\begin{tabular}{|c|c|c|c|}
\hline & $\begin{array}{l}\text { Pre-treatment } \\
\text { Median } \\
\text { (min-max) }\end{array}$ & $\begin{array}{l}\text { Post-treatment } \\
\text { Median } \\
\text { (min-max) }\end{array}$ & p \\
\hline \multicolumn{4}{|c|}{ VAS at rest } \\
\hline Group & $5(2-8)$ & $3(0-6)$ & \multirow{2}{*}{$\begin{array}{l}<0.001 \\
<0.001\end{array}$} \\
\hline Group 2 & $3(0-8)$ & $2(0-5)$ & \\
\hline \multicolumn{4}{|c|}{ VAS activit } \\
\hline $\begin{array}{l}\text { Group } 1 \\
\text { Group } 2\end{array}$ & $\begin{array}{l}8(7-10) \\
7(5-8)\end{array}$ & $\begin{array}{l}5(4-6) \\
5(0-8)\end{array}$ & $\begin{array}{l}0.001 \\
<0.001\end{array}$ \\
\hline \multicolumn{4}{|c|}{ WOMAC Pain } \\
\hline $\begin{array}{l}\text { Group } 1 \\
\text { Group } 2\end{array}$ & $\begin{array}{l}13.5(7-20) \\
10(5-18)\end{array}$ & $\begin{array}{l}7.5(3-15) \\
5(0-13)\end{array}$ & $\begin{array}{l}<0.001 \\
<0.001\end{array}$ \\
\hline \multicolumn{4}{|c|}{ WOMAC Stiffness } \\
\hline $\begin{array}{l}\text { Group } 1 \\
\text { Group } 2\end{array}$ & $\begin{array}{l}2.5(0-6) \\
2(0-6)\end{array}$ & $\begin{array}{l}0.5(0-4) \\
1(0-4)\end{array}$ & $\begin{array}{l}0.001 \\
<0.001\end{array}$ \\
\hline \multicolumn{4}{|c|}{ WOMAC Physical function } \\
\hline $\begin{array}{l}\text { Group } 1 \\
\text { Group } 2\end{array}$ & $\begin{array}{l}43(20-50) \\
34(18-52)\end{array}$ & $\begin{array}{l}25(12-39) \\
19(4-49)\end{array}$ & $\begin{array}{l}<0.001 \\
<0.001\end{array}$ \\
\hline \multicolumn{4}{|c|}{$\begin{array}{l}\text { VAS: Visuel analog scale, WOMAC: Western Ontario McMaster Osteoarthritis } \\
\text { index }\end{array}$} \\
\hline
\end{tabular}

Table 3. The comparison of treatment changes $(\Delta)$ of the clinical parameters according to baseline values

\begin{tabular}{|c|l|l|l|}
\hline \multicolumn{5}{|l|}{} & $\begin{array}{l}\text { Group 1 (n=20) } \\
\text { Median } \\
\text { (min-max) }\end{array}$ & $\begin{array}{l}\text { Group 2 (n=31) } \\
\text { Median (min-max) }\end{array}$ & p \\
\hline$\Delta$ VAS & $3(0-5)$ & $3(0-6)$ & 0.32 \\
\hline Rest & $3(0-5)$ & $3(0-6)$ & 0.32 \\
\hline Activity & $5(2-10)$ & $5(0-11)$ & 0.33 \\
\hline$\Delta$ WOMAC & $1(0-5)$ & 0.34 \\
\hline Pain & $2(0-4)$ & $14(0-33)$ & 0.99 \\
\hline \multicolumn{5}{|l|}{ Stiffness } & $14.5(7-27)$ & \\
\hline $\begin{array}{l}\text { Physical } \\
\text { function }\end{array}$ & $\begin{array}{l}\text { n: Number of patients per group, } \Delta: \text { The changes of parameters } \\
\text { VAS: Visuel analog scale, WOMAC: Western Ontario McMaster osteoarthritis } \\
\text { index Min: Minimum, Max: Maximum }\end{array}$ \\
\hline
\end{tabular}

of TENS $(17,18)$. The recommendation level of TENS in the guidelines (2014) developed by Osteoarthritis Research Society International was uncertain for knee OA (19). Chen et al. (20) evaluated the efficacy of TENS for the management of knee OA in their systematic review and meta-analysis. They found that TENS significantly decreased pain compared with control group but there was no significant difference in the WOMAC index between the TENS and control groups (20). The present study showed that both knee pain and physical function assessment parameters were improved significantly in 
knee OA with NP. Atamaz et al. (21) investigated the efficacy of electrical stimulation forms for the management of knee OA in their double-blind, randomized, controlled, multicenter trial and they showed that both knee pain and function assessment parameters were improved with TENS therapy. Cherian JJ et al. $(22,23)$ found that TENS has a significant effect on the reduction of pain in OA of the knee in their studies $(22,23)$. The results of this study are consistent with the results of the before mentioned studies in confirming the effectiveness of TENS in osteoarthritic knees but there was not a placebo TENS group in this study so we could not show the superiority of TENS treatment over placebo group.

Neuropathic mechanisms can play role in the pain of OA $(1,2)$. NP due to arthritis can lead to a marked impairment in patients' quality of life (24). In the past years, there have been a number of studies that have investigate defficacy of TENS for pain reduction in people with several pain conditions, but to our knowledge there are only a limited number of studies that use TENS for treatment of NP (7-9). TENS strengthens local inhibitory controls and is indicated in focal NP (5). The advantage of TENS therapy is that it can be used in combination with drug therapy, thus decreasing drug dosage and adverse effects. There are too few randomized controlled trials on TENS for NP to judge effectiveness (10). Kılınç et al. (25) investigated the effects of TENS therapy on pain intensity and functional capacity in patients with NP and they found that TENS therapy was effective in the NP patients. Allodynia and hyperalgesia are the two common sensation disorders in patients with NP (26). Previous studies have demonstrated that TENS is effective for decreasing mechanic hyperalgesia. Ainsworth et al. (27) found that TENS relieves primary mechanic hyperalgesia caused by joint inflammation. In this study knee patients with NP reported allodynia and hyperalgesia in their pain complaints. Pain VAS at rest, pain VAS with activity and WOMAC pain scores of the knee OA patients with NP were significantly higher than the other group. The decrease in VAS and WOMAC pain scores at the end of the treatment was statistically significant. The results of this study showed that TENS was effective in reducing pain and improving physical function in knee OA patients with NP. The European Federation of Neurological Societies determined that TENS is superior to placebo. This is based on 9 controlled trials with data obtained from 200 NP patients. Trial reports suggest that TENS is more useful than placebo for chronic pain that includes neuropathic elements (10). However, this information does not prove the lack of control group in our study. This study has several limitations. An important limitation of this study is the absence of a third group with no-treatment or sham TENS. Second we can't conclude whether hot pack and TENS without exercise have similar effects on improvement for knee pain, because there was no group consisting of use of physical therapy agents alone. Third, our follow-up period was short, we did not assess the long-term follow-up effects of TENS. Future work should purpose to evaluate patients with longer follow-up. In addition, our sample size is small that our results need to be verified by further controlled studies on a wider population.

\section{Conclusion}

This study showed that the pain intensity decreased and physical function improved significantly following TENS therapy in knee OA patients with and without NP. TENS therapy can be used in clinical practice as part of the treatment of NP in knee OAs. The advantage of TENS therapy is that it can be used in combination with drug therapy, thus decreasing drug dosage and adverse effects.

\section{Ethics}

The Local Ethics Committee of Ankara Physical Medicine and Rehabilitation Training and Research Hospital approved the study and written consent was taken from each patient.

Informed Consent: It was taken.

Peer-review: Internally peer-reviewed.

\section{Authorship Contributions}

Surgical and Medical Practices: C.S.P., Concept: C.S.P., A.D., B.F.K., Design: C.S.P., Ş.Ş.O., Data Collection or Processing: C.S.P., S.K.A., Analysis or Interpretation: C.S.P., D.S.Ö., Literature Search: C.S.P., Writing: C.S.P.

Conflict of Interest: No conflict of interest was declared by the authors.

Financial Disclosure: The authors declared that this study received no financial support.

\section{References}

1. Kidd BL, Langford RM, Wodehouse T. Arthritis and pain. Current approaches in the treatment of arthritic pain. Arthritis Res Ther 2007;9:214

2. Kosek E, Ordeberg G. Abnormalities of somatosensory perception in patients with painful osteoarthritis normalize following successful treatment. Eur J Pain 2000;4:229-38.

3. Vance CG, Rakel BA, Blodgett NP, DeSantana JM, Amendola A, Zimmerman $\mathrm{MB}$, et al. Effects of transcutaneous electrical nerve stimulation on pain, pain sensitivity, and function in people with knee osteoarthritis: a randomized controlled trial. Phys Ther 2012;92:898-910.

4. Santuzzi CH, Neto Hde A, Pires JG, Gonçalves WL, Gouvea SA, Abreu GR. High-frequency transcutaneous electrical nerve stimulation reduces pain and cardio-respiratory parameters in an animal model of acute pain: Participation of peripheral serotonin. Physiother Theory Pract 2013;29:630-8.

5. Guastella V, Mick G, Laurent B. Non pharmacologic treatment of neuropathic pain. Presse Med 2008;37:354-7.

6. Kim J, Jung JI, Na HS, Hong SK, Yoon YW. Effects of morphine on mechanical allodynia in a rat model of central neuropathic pain. Neuroreport 2003;23:14:1017-20.

7. Dubinsky RM, Miyasaki J. Assessment: efficacy of transcutaneous electric nerve stimulation in the treatment of pain in neurologic disorders (an evidence-based review) report of the Therapeutics and Technology Assessment Subcommittee of the American Academy of Neurology. Neurology 2010;74:173-6.

8. Luk ML. The effectiveness of transcutaneous electrical nerve stimulation on neuropathic pain. Hong Kong Physiotherapy Journal 2002;20:32.

9. Cuypers K, Levin O, Thijs H, Swinnen SP, Meesen RL. Longterm TENS treatment improves tactile sensitivity in MS patients. Neurorehabil Neural Repair 2010;24:420-7. 
10. Johnson MI, Bjordal JM. Transcutaneous electrical nerve stimulation for the management of painful conditions: focus on neuropathic pain. Expert Rev Neurother 2011;11:735-53.

11. Kellgren JH, Lawrence JS. Radiological assessment of osteoarthrosis. Ann Rheum Dis 1957;16:494-502.

12. Freynhagen R, Baron R, Gockel U, Tölle TR. PainDETECT: a new screening questionnaire to identify neuropathic components in patients with back pain. Curr Med Res Opin 2006;22:1911-20.

13. Alkan $H$, Ardic F, Erdogan C, Sahin F, Sarsan A, Findikoglu $G$. Turkish version of the painDETECT questionnaire in the assessment of neuropathic pain: a validity and reliability study. Pain Med 2013;14:1933-43.

14. Tok F, Aydemir K, Peker F, Safaz I, Taşkaynatan MA, Özgül A. The effects of electrical stimulation combined with continuous passive motion versus isometric exercise on symptoms, functional capacity, quality of life and balance in knee osteoarthritis: randomized clinical trial. Rheumatol Int 2011;31:177-81.

15. Tüzün $E$, Eker L, Aytar A, Daşkapan A, Bayramoğlu $M$. Acceptability, reliability, validity and responsiveness of the Turkish version of WOMAC osteoarthritis index. Osteoarthritis Cartilage 2005;13:28-33.

16. Yildiz SK, Özkan FÜ, Aktaş I, Silte AD, Kaysin MY, Badur NB. The effectiveness of ultrasound treatment for the management of kneeosteoarthritis: a randomized, placebo-controlled, doubleblind study. Turk J Med Sci 2015;45:1187-91.

17. Bjordal JM, Johnson MI, Lopes-Martins RA, Bogen B, Chow R, Ljunggren AE. Short-term efficacy of physical interventions in osteoarthritic knee pain. A systematic review and meta-analysis of randomised placebo-controlled trials. BMC Musculoskelet Disord 2007;8:51

18. Rutjes AW, Nüesch E, Sterchi R, Kalichman L, Hendriks E, Osiri M, et al. Transcutaneous electrostimulation for osteoarthritis of the knee. Cochrane Database Syst Rev 2009:CD002823.
19. McAlindon T, Bannuru RR, Sullivan M, Arden N, Berenbaum F, Bierma-Zeinstra SM, et al. OARSI guidelines for the non-surgical management of knee osteoarthritis. Osteoarthritis Cartilage 2014;22:363-88

20. Chen LX, Zhou ZR, Li YL, Ning GZ, Li Y, Wang XB, et al. Transcutaneous Electrical Nerve Stimulation in Patients With Knee Osteoarthritis: Evidence From Randomized-controlled Trials. Clin J Pain 2016;32:146-54.

21. Atamaz FC, Durmaz B, Baydar M, Demircioglu OY, Iyiyapici A, Kuran $B$, et al. Comparison of the efficacy of transcutaneous electrical nerve stimulation, interferential currents, and shortwave diathermy in knee osteoarthritis: a double-blind, randomized, controlled, multicenter study. Arc Phys Med Rehabil 2012;93:748-56.

22. Cherian JJ, Jauregui JJ, Leichliter AK, Elmallah RK, Bhave A, Mont MA. The effects of various physical non-operative modalities on the pain in osteoarthritis of the knee. Bone Joint J 2016;98(Suppl 1):89-94.

23. Cherian JJ, Harrison PE, Benjamin SA, Bhave A, Harwin SF, Mont MA. Do the Effects of Transcutaneous Electrical Nerve Stimulation on Knee Osteoarthritis Pain and Function Last? J Knee Surg 2016;29:497-501.

24. Mitchell C. Assessment and management of chronic pain in elderly people. Br J Nurs 2001;10:296-304.

25. Kılınç M, Livanelioğlu A, Yıldırım SA, Tan E. Effects of transcutaneous electrical nerve stimulation in patients with peripheral and central neuropathic pain. J Rehabil Med 2014;46:454-60.

26. DeSantana JM, Walsh DM, Vance C, Rakel BA, Sluka KA. Effectiveness of transcutaneous electrical nerve stimulation for treatment of hyperalgesia and pain. Current rheumatology reports 2008;10:492-9.

27. Ainsworth L, Budelier K, Clinesmith $M$, Fiedler A, Landstrom R, Leeper B, et al. Transcutaneous electrical nerve stimulation (TENS) reduces chronic hyperalgesia induced by muscle inflammation. Pain 2006;120:182-7. 